\title{
The Discussion of Kano Two-Dimensional Quality Mode on the Essential Service Quality Attributes of Taiwan Power Company
}

\author{
Chang-Hsien Hsu, Chiu-Yu Hung, Yu-Hsuan Lan, and Zheng-Ji Chen
}

\begin{abstract}
Taiwan Power Company (T-Company) is the only power generation company in Taiwan. However, as a state-owned enterprise with exclusive market, its service items and service quality often have a gap with the expectations of the people. Therefore, this study used the SERVQUAL scale to investigate the service quality elements of a business district in the central part of the Taiwan Power Company, and explored the service quality attributes of Taiwan Power Company in conjunction with the two-dimensional quality model of Kano. Using questionnaires is to understand the importance of the service elements from the points of view of the public? According to the statistical results, among the service quality factors, there are 7 one-dimensional quality elements, 3 attractive quality elements, 8 indifference quality elements, and 9 Must-be quality elements. It is recommended that T-Company can promote their services with the survey results. The elements are improved to further enhance their service quality so as to implement the concept of sustainable business.
\end{abstract}

Index Terms-T-Company, Kano two-dimensional quality mode, service quality, SERVQUAL questionnaire.

\section{INTRODUCTION}

Electricity is the most important source of economic development and the force of industry and commerce, and the most indispensable element in the modern life. From the general traditional industries to high-tech industries, all use electricity as the main source of power. For Taiwan, which lacks its own energy, how to provide abundant and stable power for economic development is important. The comfortable life and convenience of the people has become the most important indicator of the entire country.

T-Company has been established for more than seventy years since it was established in 1946. It is a comprehensive power company covering electricity generation, transmission, distribution and sale of electricity. It is also the only power industry company in Taiwan. As for private power plants and private enterprises, the electricity generated by power generation and cogeneration of electricity and it must also be sold to T-Company, and then distributed to the users via T-Company [1]. For the service quality of T-Company, in recent years, whether it is Taiwanese industry or electricity consumption in the people's livelihood, the demand has increased much compared with the early stage. The power

Manuscript received August 15, 2019; revised March 7, 2020.

The authors are with the Department of Business Administration, Asia University, Taiwan (e-mail: taylor@wellball.com.tw). supply and the stability that the people rely on are all included in T-Company. In the service content, that is, when the power supply is unstable or the power supply causes power outages today, it is not only inconvenient for people's lives, but also difficult to estimate the losses caused by enterprises. Based on the above, it can be found that T-Company plays a very important and important role in the entire economy of the country and in providing a comfortable life for the people.

Nowadays, there are more and more enterprises with service quality as the future development direction. After improving the service quality, it can bring considerable profits to the company. On the other hand, there is a certain degree of improvement.to the people in terms of satisfaction and loyalty, even the corporate image. Therefore, this study was proposed by Noriaki Kano et al. in 1984. The service itself must have multiple attributes of quality, and the satisfaction of customers is not only explained by a single attribute, but also Kano Kisho proposed Kano's two-dimensional quality model to verify, using Kano's two-dimensional quality model to verify the characteristics of T-Company's service quality level. Through questionnaires, to further understand the public's demand for service quality of T-Company. Based on the statistical results of the questionnaire, the most urgent need for improvement of the T- Company at this stage is proposed as a proposal to enhance the company's future business.

\section{METHODOLOGY}

\section{A. Service Quality Measurement}

The quality of service has different opinions on the definition of different types of industries. In view of this, three scholars, Parasursman, Zeithaml and Berry, put forward relevant explanations and values for service quality [2]. Aiming at service quality, a set of theoretical applications is proposed, which is also widely used by academics and industry to measure the quality of service.

In 1988, Parasursman, Zeithaml and Berry further developed the ten facets of the service quality determinants proposed which from the thoughts in 1985 [3]. They are used as the basis to extract the five dimensions of service quality we have seen so far, and proposed SERVQUAL. The scale (as shown in Table I), after the revision of the 22 evaluation items of the SERVQUAL scale in 1991, was widely used as a measure of service quality as a measure of the quality of 
service items [4].

\begin{tabular}{cl}
\multicolumn{2}{c}{ TABLE I: SERVQUAL QUESTIONNAIRE } \\
\hline dimention & \multicolumn{1}{c}{ Description } \\
\hline Tangibles & $\begin{array}{l}\text { Refers to the actual facilities, equipment, and staff } \\
\text { services }\end{array}$ \\
\hline Reliability & Refers to reliable and correct service delivery \\
\hline Responsiveness & $\begin{array}{l}\text { Refers to services that are willing to assist customers } \\
\text { and provide immediate }\end{array}$ \\
\hline Assurance & $\begin{array}{l}\text { Refers to the ability to have professional knowledge, } \\
\text { courtesy and the ability to convey trust and } \\
\text { confidence }\end{array}$ \\
\hline Empathy & $\begin{array}{l}\text { Refers to the ability to provide customers with } \\
\text { personalized care }\end{array}$ \\
\hline Data Source: Parasursman, Zeithaml and Berry(1988)
\end{tabular}

This study is based on the T-Company and uses of the five major facets of the SERVQUAL scales proposed by Parasuraman et al., including tangible, reliability, responsiveness, empathy and assurance, and its facet will affect the operational definition of the elements of service quality. The relevant descriptions are as follows:

\section{1) Tangible}

It refers to the actual facilities, hardware and software equipment, service personnel and visible signs of the T-Company which Includes providing multiple places for payment, providing a rich payment method, neat and tidy service staff, providing complete modern facilities and diversified service channels

\section{2) Reliability}

It refers to the ability of T-Company itself to truly and correctly perform the relevant commitments to users which include: electricity bills and receipts on time, maintaining low and reasonable electricity prices, T-Company's reputation and image, maintaining good power quality, billing and meter reading records are accurate and credible, providing electricity usage and billing methods, The service staff is enthusiastic and enthusiastic, and the application for electricity can supply electricity on schedule.

\section{3) Responsiveness}

It means that T-Company can provide users with immediate services which including: Proactively inform the user of the payment situation, the time required to apply for electricity to complete, the convenient inquiry and printing of payment information, the download of the online application project form, and the acceptance of the case can be solved in time.

\section{4) Assurance}

It refers to the professional knowledge and professionalism of the service personnel of T-Company, which is worthy of the trust of the audience. Including: It can restore power supply in the shortest time, the service staff treats the user with kindness, and the power outage can restore the power supply according to the notification time, and the service personnel provide the correct consulting service.

\section{5) Empathy}

It means that T-Company can provide users with personalized care and caring services including: the apology caused by the power failure of the perineal facilities, the service personnel actively understand the user's needs, proactively notify the scheduled construction power outage time, actively care about the user's rights and interests, and actively track the user's complaints or complaints.

\section{B. Kano Two-Dimensional Quality Mode}

The concept of two-dimensional quality can be traced back to the "two theory of job attitudes" proposed by psychologist Herzberg in 1959. The earliest use is mainly used in the incentives of organizational behavior employees, also known as the "incentive health theory" [5]. The Kano two-dimensional quality model was modified by Kano, Seraku, Takahashi, and Tsuji in 1984 according to the two-factor theory proposed by Herzberg et al. [6].

According to Fig. 1, the abscissa indicates the degree of possession of a certain quality element. If the indication goes to the right, the higher the degree of possession of the quality attribute is. If the indication goes to the left, the higher the quality attribute is. As for the ordinate standard, it indicates the degree of satisfaction of the consumer or the user. For example, the higher the axis, the higher the degree of satisfaction, and the higher the lower axis, the higher the degree of dissatisfaction.

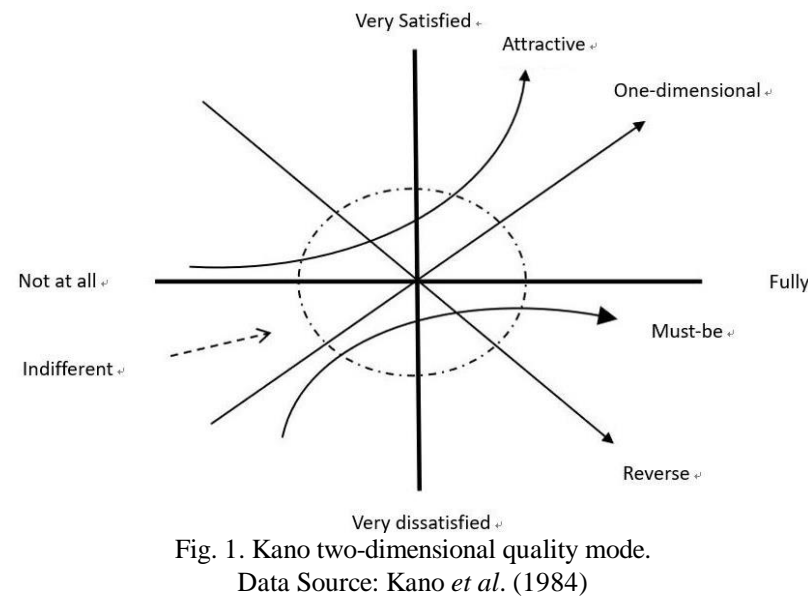

In addition, according to the opposite relationship between the horizontal and vertical axes of the figure, the quality elements can be divided into five major groups (Table II).

TABLE II: FIVE MAJOR GROUPS OF QUALITY ELEMENTS

\begin{tabular}{cl}
\hline Quality elements & \multicolumn{1}{c}{ Description } \\
\hline Attractive & $\begin{array}{l}\text { It means that when the quality of service is available, } \\
\text { consumers will be quite satisfied, but when the factors } \\
\text { are lacking, consumers will not be dissatisfied. }\end{array}$ \\
\hline $\begin{array}{c}\text { one-dimensional } \\
\text { quality }\end{array}$ & $\begin{array}{l}\text { If one-dimensional quality is available, it will be } \\
\text { satisfied by consumers, and the higher the degree of } \\
\text { possession, the more satisfied consumers will be. On the } \\
\text { other hand, if it is not available, it will be less satisfied, } \\
\text { so the degree of satisfaction and the supply of factors are } \\
\text { linear. }\end{array}$ \\
\hline Must-be quality & $\begin{array}{l}\text { Must-be quality means that even if the quality of service } \\
\text { is available, it will not cause consumer satisfaction, but } \\
\text { when it does not, it will immediately cause consumer } \\
\text { dissatisfaction. }\end{array}$ \\
\hline Indifference & $\begin{array}{l}\text { Indifference quality refers to whether the elements of the } \\
\text { ministry are available, and will not cause consumer } \\
\text { satisfaction or dissatisfaction }\end{array}$ \\
\hline The reverse & $\begin{array}{l}\text { This element will cause dissatisfaction among } \\
\text { consumers, but will not be satisfied }\end{array}$ \\
\hline Data Source: The description of Kano two-dimensional quality mode
\end{tabular}




\section{Classification of Kano Two-Dimensional Quality Mode}

As for the classification method of two-dimensional quality elements, this study is mainly based on Matzler and Hinterhuber's method of classification [7]. Its answer items are shown in Table III: like, of cource, no opinion, bearable, dislike. And for each quality factor, there will be different perceptions for different respondents, and the assessment results will be different, so each quality factor may occur. Usually, when dealing with the distribution of factors, it will be based on statistically "significant" as the basis of the classification, that is, which element is selected by the most number.

TABLE III: CLASSIFICATION OF KANO TwO-DIMENSIONAL QUALITY MODE reverse like Of course No opinion bearable dislike \begin{tabular}{cccccc} 
positive & & & & \\
& invalid & Attractive & Attractive \\
quality & quality & quality & Attractive & quality & $\begin{array}{c}\text { One- } \\
\text { dimensional } \\
\text { quality }\end{array}$ \\
\hline Of course & reverse & indifference & indifference & indifference & indifference \\
& quality & quality & quality & quality & quality \\
\hline No opinion & reverse & indifference & indifference & indifference & indifference \\
& quality & quality & quality & quality & quality \\
\hline Bearable & reverse & indifference & indifference & indifference & indifference \\
& quality & quality & quality & quality & quality \\
\hline Dislike & reverse & reverse & reverse & reverse & invalid \\
& quality & quality & quality & quality & quality
\end{tabular}

Data Source: Matzler, k. \& Hinterhuber, H. H.(1998)

In addition, according to the quality improvement indicators proposed by Matzler \& Hinterhuber [7], it is also considered that in the measurement of service quality indicators. If some unsatisfactory quality standards are to be improved, the increase or decrease of satisfaction or dissatisfaction will be between -1 . That is, when the satisfaction increment index (SII) is increased, the closer the value of the calculation result is to 0 , the lower the degree of influence, and the closer to +1 , the higher the satisfaction of the consumer. Significantly improved; reduce the dissatisfaction index (DDI), the result of the calculation is closer to 0 , indicating that the lower the degree of influence, and the closer to -1 , the greater the impact of the lack of quality factors on dissatisfaction.

Increase satisfaction index: $(\mathrm{A}+\mathrm{O}) /(\mathrm{A}+\mathrm{O}+\mathrm{M}+\mathrm{I})$

Decrease dissatisfaction index: $(\mathrm{O}+\mathrm{M}) /(\mathrm{A}+\mathrm{O}+\mathrm{M}+\mathrm{I})(-1)$

$\mathrm{A}$ : attractive quality; $\mathrm{O}$ : one-dimensional quality;

M: Must-be quality; I: indifference quality.

\section{RESEARCH RESULTS AND ANALYSIS}

\section{A. Kano Two-Dimensional Quality Classification of T-Company}

In this study, the questionnaires were collated and analyzed by Kano's two-dimensional quality model, and according to the calculation method of Kano's quality attribute classification ratio, the second part of the service quality of the questionnaire was "available" and "Not available", to understand the public's awareness of the service quality of T-Company and its lack of quality, and further calculate the results of the effective questionnaires in a cumulative manner, the highest one becomes the quality attribute of this item Class. But if there are different two-dimensional quality classifications, the cumulative number is the same, then the final judgment is based on the criterion of classification of two-dimensional quality characteristics $\mathrm{M}>\mathrm{O}>\mathrm{A}>\mathrm{I}$ [8]. The following is a classification of the Kano element quality attributes for this questionnaire, as shown in Table IV:

TABLE IV: KANO TWO-DIMENSIONAL QUALITY CLASSIFICATION OF T-COMPANY

Item Kano two-dimensional quality classification of Classification

\begin{tabular}{|c|c|c|c|c|c|c|c|}
\hline & \multicolumn{6}{|c|}{ T-Company } & \\
\hline & $\mathrm{A}$ & $\mathrm{O}$ & $\mathrm{M}$ & $\mathrm{I}$ & $\mathrm{R}$ & $\mathrm{Q}$ & \\
\hline 1 & 54 & 141 & 39 & 42 & 0 & 0 & $\mathrm{O}$ \\
\hline 2 & 33 & 153 & 30 & 60 & 0 & 0 & $\mathrm{O}$ \\
\hline 3 & 42 & 42 & 45 & 141 & 6 & 0 & I \\
\hline 4 & 51 & 36 & 108 & 78 & 3 & 0 & $\mathrm{M}$ \\
\hline 5 & 48 & 75 & 27 & 123 & 3 & 0 & $\mathrm{I}$ \\
\hline 6 & 21 & 78 & 147 & 27 & 3 & 0 & $\mathrm{M}$ \\
\hline 7 & 54 & 171 & 45 & 6 & 0 & 0 & $\mathrm{O}$ \\
\hline 8 & 57 & 48 & 57 & 111 & 3 & 0 & I \\
\hline 9 & 33 & 66 & 96 & 78 & 3 & 0 & $\mathrm{M}$ \\
\hline 10 & 57 & 135 & 54 & 30 & 0 & 0 & $\mathrm{O}$ \\
\hline 11 & 87 & 69 & 57 & 60 & 3 & 0 & $\mathrm{~A}$ \\
\hline 12 & 72 & 66 & 84 & 45 & 6 & 3 & $\mathrm{M}$ \\
\hline 13 & 39 & 141 & 30 & 66 & 0 & 0 & $\mathrm{O}$ \\
\hline 14 & 63 & 60 & 69 & 81 & 3 & 0 & I \\
\hline 15 & 39 & 99 & 108 & 24 & 3 & 3 & $\mathrm{M}$ \\
\hline 16 & 54 & 105 & 45 & 72 & 0 & 0 & $\mathrm{O}$ \\
\hline 17 & 30 & 81 & 36 & 129 & 0 & 0 & I \\
\hline 18 & 45 & 108 & 72 & 51 & 0 & 0 & $\mathrm{O}$ \\
\hline 19 & 12 & 96 & 120 & 48 & 0 & 0 & $\mathrm{M}$ \\
\hline 20 & 60 & 63 & 102 & 48 & 3 & 0 & $\mathrm{M}$ \\
\hline 21 & 39 & 78 & 108 & 42 & 3 & 6 & $\mathrm{M}$ \\
\hline 22 & 45 & 63 & 75 & 87 & 3 & 3 & I \\
\hline 23 & 45 & 54 & 57 & 117 & 3 & 0 & I \\
\hline 24 & 129 & 42 & 21 & 81 & 3 & 0 & $\mathrm{~A}$ \\
\hline 25 & 45 & 54 & 108 & 60 & 6 & 3 & $\mathrm{M}$ \\
\hline 26 & 87 & 63 & 45 & 75 & 6 & 0 & A \\
\hline 27 & 39 & 48 & 72 & 117 & 0 & 0 & I \\
\hline
\end{tabular}

A: attractive quality, $\mathrm{O}$ : one-dimensional quality, $\mathrm{M}$ : Must-be quality, I: indifference quality, R: Reverse quality, Q: Unable to judge

After the collection and analysis, this study found that 27 items are mainly divided into four categories: attractive quality, one-dimensional quality, Must-be quality, and indifference quality, and the four categories are sorted by Must-be quality>Indifference quality>one-dimensional quality>attractive quality(Table V) [9], [10]:

(1) Must-be quality (M): A total of 9 items, showing that most people think that the service item should be available to the T-Company itself. Therefore, we must pay attention to the service quality of this part to avoid the increase of people's dissatisfaction.

(2) indifference quality (I): A total of 8 items, indicating that T-company's services in this part may be less for the public. Being able to get in touch with the experience, so it is more difficult for the public to answer the part of the service quality with actual and expected values. In comparison, in other words, the Taiwan Power Company can reduce the number of services in this part and use the resources saved to other services. 
(3) One-dimensional quality (O): A total of seven items, showing that Taiwan's power companies should invest more and more resources in this part. Improving the quality of service, if the quality of service can be improved, the relative satisfaction of the people will be higher; on the contrary, if its service quality is reduced, and the satisfaction of the people will decrease.
(4) Attractive quality (A): A total of 3 items, showing that if the Taiwan Power Company provides this service, the people will be satisfied, and even if T-Company does not provide this service, the public will not feel unhappy, which means that if T-Company can play this well, the service of the three projects can greatly enhance the satisfaction of the audience.

TABLE V: KANO TWO-DIMENSIONAL QUALITY CLASSIFICATION OF T-COMPANY

\begin{tabular}{|c|c|}
\hline Clas: & cation \\
\hline \multirow{9}{*}{$\begin{array}{c}\text { Must-be } \\
\text { quality }\end{array}$} & 4. The company has a complete set of modern facilities, such as wireless Internet access and other services \\
\hline & 6. The electricity fee notice and the receipt are sent on time, no delay \\
\hline & 9. T-Company maintains stable supply voltage and frequency and good power quality \\
\hline & 12. The service attitude of T-Company service personnel is very positive and enthusiastic, and the attitude is good. \\
\hline & 15. The user needs to use the power to complete the power supply, and the overall working time required is short. \\
\hline & 19. Equipment maintenance personnel have high efficiency in repairing and can restore power supply in the shortest time. \\
\hline & 20. The service staff treats the user cordially \\
\hline & 21. Each work power outage can be restored according to the time notified in advance. \\
\hline & 25. The company will take the initiative to inform the customer to book the date and time of the construction blackout. \\
\hline \multirow{8}{*}{$\begin{array}{c}\text { indifference } \\
\text { quality }\end{array}$} & 3. The service staff's grooming is neat and dignified \\
\hline & 5. Diversified company service channels, such as telephone, internet, fax, email, etc. \\
\hline & 8. T-Company has a good reputation and good image. \\
\hline & 14. T-Company will take the initiative to inform users of the payment situation message. \\
\hline & 17. The company can provide the service items and application form download for online bidding. \\
\hline & 22. Service personnel can provide correct, professional and safe electricity knowledge and technical consulting services \\
\hline & 23. The company will apologize to the user for power failure caused by equipment failure. \\
\hline & 27. The company will take the initiative to understand and track the user's complaints or complaints \\
\hline \multirow{7}{*}{$\begin{array}{c}\text { One-dimen } \\
\text { sional } \\
\text { quality }\end{array}$} & $\begin{array}{l}\text { 1. The company provides a number of places to pay, such as convenience stores, post offices, banks, and various fisheries. } \\
\text { Electricity payment is quite convenient }\end{array}$ \\
\hline & 2. The company provides a rich and selective payment method, such as deposit deduction, credit card, etc. \\
\hline & 7. T-Company maintains a low and reasonable price \\
\hline & 10. T-Company billing and meter reading records are accurate and credible \\
\hline & 13. Power application can supply power according to user's demand schedule \\
\hline & 16. Company payment inquiry, bill printing, replenishment information inquiry convenience \\
\hline & 18. The service staff can provide instant service, and the case or user consultation can be obtained in the first time. \\
\hline \multirow{3}{*}{$\begin{array}{l}\text { Attractive } \\
\text { quality }\end{array}$} & 11. The electricity and electricity bill notice provides detailed power usage, correct amount and billing method \\
\hline & 24. Service personnel will take the initiative to understand the needs of users \\
\hline & $\begin{array}{l}26 \text {. The company will take the initiative to care about the rights and interests of users, such as the two-year resumption } \mathrm{p} \\
\text { remind the monthly electricity bill payment period limit }\end{array}$ \\
\hline
\end{tabular}

\section{B. T-Company Customer Satisfaction Coefficient}

According to the results compiled in the above table, it shows that the service quality attributes of T-Company include four categories: Must-be quality, indifference quality, one-dimensional quality and attractive quality. Must-be quality part is that the audience believes that the service element itself should be available. When the service element is not available, the audience's satisfaction will be reduced; the part of the indifference quality indicates that the service element "yes" or "no" will not affect the audience's satisfaction level; the one-dimensional quality part indicates that the audience's satisfaction has a positive relationship with the service. That is, when the service quality is available, the audience's satisfaction will increase, but when the service quality is not available, the audience will feel dissatisfied. The part of the attractive quality means that the audience will be satisfied when the service elements are available, but the audience will not feel dissatisfied when the service element is not available.

In addition to the above analysis, this study also uses the increase of customer satisfaction coefficient (SII) and the reduction of customer dissatisfaction coefficient (DDI) to analyze the quality of service. The research and statistical results show that the customer satisfaction coefficient is between 0.3 and 0.8 , the customer dissatisfaction coefficient is between -0.2 and -0.9 , while the average customer satisfaction coefficient is 0.490 , and the customer dissatisfaction coefficient is -0.555 . The average value of the person is taken as the center point of the $\mathrm{X}$-axis (increasing the customer satisfaction index) and the $\mathrm{Y}$-axis (reducing the customer dissatisfaction index), and the SII-DDI two-dimensional dot pattern is drawn, and the distribution is as shown in the following figure:

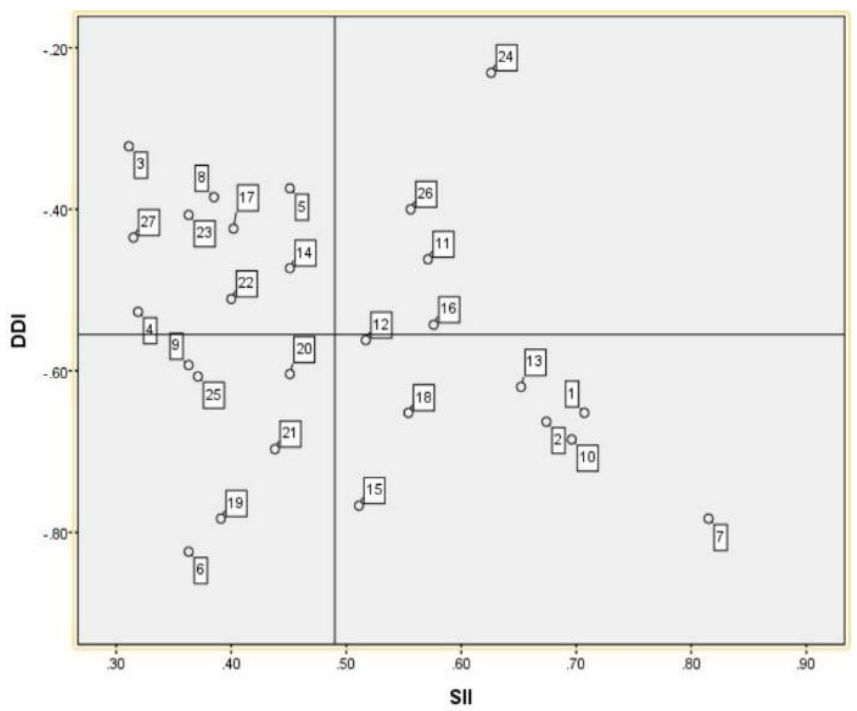

Fig. 2. SII-DDI two-dimensional scatter diagram. 
The Table $\mathrm{V}$ is a table drawn from the study for increasing customer satisfaction and reducing customer dissatisfaction for each item. Through this table, we can clearly understand what needs T-Company to strengthen and improve the various elements of its service quality. If the customer satisfaction index is closer to 1 , it means that the more needs to be improved, the improvement for this part can be Effectively improve customer satisfaction indicators; and reduce the customer dissatisfaction indicators closer to -1 , indicating that these service items need to be prioritized to improve the customer's dissatisfaction indicators, and the effect will be most significant.

TABLE VI: INCREASE SATISFACTION INDEX \& DECREASE DISSATISFACTION INDEX

\begin{tabular}{|c|c|c|c|}
\hline dimention & item & SII & DDI \\
\hline \multirow{4}{*}{ Tangibles } & $\begin{array}{l}\text { 1. The company provides a number of places to pay, such as convenience stores, post offices, banks, and various } \\
\text { fisheries. Electricity payment is quite convenient }\end{array}$ & 0.707 & -0.652 \\
\hline & 2. The company provides a rich and selective payment method, such as deposit deduction, credit card, etc. & 0.674 & -0.663 \\
\hline & 4. The company has a complete set of modern facilities, such as wireless Internet access and other services & 0.319 & -0.527 \\
\hline & 5. Diversified company service channels, such as telephone, internet, fax, email, etc. & 0.451 & -0.374 \\
\hline \multirow{8}{*}{ Reliability } & 6. The electricity fee notice and the receipt are sent on time without delay & 0.363 & -0.824 \\
\hline & 7. T-Company maintains a low and reasonable price & 0.815 & -0.783 \\
\hline & 8. T-Company has a good reputation and good image. & 0.385 & -0.385 \\
\hline & 9. T-Company maintains stable supply voltage and frequency and good power quality & 0.363 & -0.593 \\
\hline & 10. T-Company billing and meter reading records are accurate and credible & 0.696 & -0.685 \\
\hline & 11. The electricity and electricity bill notice provides detailed power usage, correct amount and billing method & 0.571 & -0.462 \\
\hline & 12. The service attitude of T-Company service personnel is very positive and enthusiastic, and the attitude is good. & 0.517 & -0.562 \\
\hline & 13. Power application can supply power according to user's demand schedule & 0.652 & -0.620 \\
\hline \multirow{4}{*}{ Responsiveness } & 14. T-Company will take the initiative to inform users of the payment situation message. & 0.451 & -0.473 \\
\hline & 15. The user needs to use the power to complete the power supply, and the overall working time required is short. & 0.511 & -0.767 \\
\hline & 17. The company can provide the service items and application form download for online bidding. & 0.402 & -0.424 \\
\hline & 18. The service staff can provide instant service, and the case or user consultation can be obtained in the first time. & 0.554 & -0.652 \\
\hline \multirow[t]{4}{*}{ Assurance } & $\begin{array}{l}\text { 19. Equipment maintenance personnel have high efficiency in repairing and can restore power supply in the } \\
\text { shortest time. }\end{array}$ & 0.391 & -0.783 \\
\hline & 20. The service staff treats the user cordially & 0.451 & -0.604 \\
\hline & 21. Each work power outage can be restored according to the time notified in advance. & 0.438 & -0.697 \\
\hline & $\begin{array}{l}\text { 22. Service personnel can provide correct, professional and safe electricity knowledge and technical consulting } \\
\text { services }\end{array}$ & 0.400 & -0.511 \\
\hline \multirow{5}{*}{ Empathy } & 23. The company will apologize to the user for power failure caused by equipment failure. & 0.363 & -0.407 \\
\hline & 24. Service personnel will take the initiative to understand the needs of users & 0.626 & -0.231 \\
\hline & $\begin{array}{l}25 \text {. The company will take the initiative to inform the customer to book the date and time of the construction } \\
\text { blackout. }\end{array}$ & 0.371 & -0.607 \\
\hline & $\begin{array}{l}26 \text {. The company will take the initiative to care about the rights and interests of users, such as the two-year } \\
\text { resumption period or remind the monthly electricity bill payment period limit }\end{array}$ & 0.556 & -0.400 \\
\hline & 27. The company will take the initiative to understand and track the user's complaints or complaints & 0.315 & -0.435 \\
\hline
\end{tabular}

According to the results of increasing customer satisfaction and reducing customer dissatisfaction indicators calculated in the above, you can clearly understand the items of different facets, and which needs to be improved or improved first. The following authors will focus on the five facets and items related instructions:

\section{1) Tangible}

It refers to the actual facilities, hardware and software equipment, service personnel and visible signs of T-Company and increase to the customer satisfaction index. "The company provides a number of places where it can be paid, such as convenience stores, post offices, banks, and various fisheries and fisheries, and the payment of electricity is very convenient." This is the most important item to be improved. If T-Company can lower it, that is, the user's sales information of the collection party is synchronized with T-Company, and regular updates and care are carried out to reduce the expected gap of the people in a timely manner, which can effectively improve the satisfaction of the public; and reduce the dissatisfaction of the customers. In the part, "the company provides a rich and selective payment method, such as deposit deduction, credit card, etc." as a priority improvement item, indicating that with the improvement of the quality of the people and the changes in the environment, all aspects of T-Company are It is highly valued by the people, the most obvious of which is the variety of options for payment methods. If you can provide more diverse and safe payment methods, you can greatly reduce customer dissatisfaction.

\section{2) Reliable}

It means that T-Company can be trusted by the people and promises to serve the people. In terms of increasing customer satisfaction, "Taiwan maintains low and reasonable electricity prices" is the most important item to improve. It can be found that T-Company is the leader of T-Company Power. The fluctuation of electricity prices is the most direct relationship between people's use and burden impact, if this part of the company can maintain stable and low electricity bills, it will certainly enhance the public's satisfaction with T-Company. In terms of reducing customer dissatisfaction, "electricity notices and receipts are sent on time without delay. "This is the product with the highest priority. This also shows that if the T-Company Company can send the electricity bills to the people on time, there is no delay in paying the electricity bills on time, which not only improves the satisfaction of the people, but also reduces the public's Dissatisfaction indicator.

\section{3) Responsiveness}

It means that T-Company can provide immediate help and 
services to the public. In terms of increasing customer satisfaction, this facet is the most important item to improve by "company payment inquiry, bill printing, and payment of information inquiry convenience", that is, if T-Company can provide relevant and convenient inquiry service. It can affect people's perception of T-Company as a whole, and the public should improve their satisfaction. As for reducing customer dissatisfaction, the "the overall operation time required for users to apply for electricity to complete the power supply is short" is the most important improvement product. In short, people generally want to be more convenient and have shorter time to apply for electricity. If T-Company waits for people to wait too long, the people will naturally increase their dissatisfaction. From this point of view, it can be clearly understood that for the T-Company, not only the facilities and equipment must have a certain degree of performance, but the people also attach great importance to the immediacy and convenience of T-Company. T-Company cannot be ignored in this part.

\section{4) Assurance}

It refers to the expertise, ability and trust that T-Company can provide to the people who come to the public. In this facet, the increase in customer satisfaction is based on the fact that "the service staff treats the user with kindness and courtesy" as the most important item of improvement, indicating that the service personnel's service attitude is good and friendly, which can completely affect the public's perception of the overall situation of T-Company. Therefore, if the service personnel of T-Company can improve the service quality, the public should improve their satisfaction. As for the reduction of customer dissatisfaction, the "equipment maintenance personnel have high efficiency in repairing and can restore power supply in the shortest time" is the highest priority. The improved items indicate that the people attach great importance to the power outage caused by accidents or natural disasters. Not only are they inconvenient in all aspects of life, but they may further cause people's property losses. Therefore, this part is more important for the importance of power contingency measures. It can reduce the degree of dissatisfaction of the audience.

\section{5) Empathy}

It means that T-Company can provide the people with personal care and attention, and stand on the people's standpoint as the starting point. According to the increase of customer satisfaction index, "the service staff will take the initiative to understand the user's needs" is the most important item to be improved. This also reflects the fact that T-Company has shown that the company cares and cares for each customer. In other words, if T-Company can invest more in this aspect and understand the needs of the people, it can effectively improve customer satisfaction. As for the part that reduces customer dissatisfaction, the company will take the initiative to notify customers to book the date and time of the construction blackout. The item, this part is the right to "know" the people. On the one hand, the people feel that they are valued, on the other hand, it does not cause inconvenience to the people, that is, if T-Company can consider it at the beginning of the construction period. The convenience of the people is to reduce the dissatisfaction of the audience.

\section{CONCLUSION}

In this paper, the five facets of the SERVQUAL scale are used as the basis of the questionnaire structure, and the general user group of a certain business district in the middle of the T-Company is used as the questionnaire, and the service quality attribute of T-Company is discussed in combination with the two-dimensional quality model of Kano. By calculating the customer satisfaction factor when sufficient each service quality factor is sufficient and reducing the customer dissatisfaction coefficient when not enough, to further understand which service items are "priority improvement" or "key service" elements, thereby gaining a deeper understanding of the public for T-Company. The company's perspective on service quality and importance.

In this study, among the service quality factors of T-Company, 7 items of one-dimensional quality elements are included in the statistics. It can be seen that the masses hope that T-Company should invest more and more resources for this part, when its demand for service quality reaches a certain level. After that, not only can the people be satisfied, but the people will be more satisfied with the satisfaction. On the contrary, if the quality of service does not meet the requirements of the people, the satisfaction of the people will also decrease. Then there are 3 elements of the quality of charm. This part of the project T-Company must continue to maintain, and further can create and shape the unique operating characteristics of T-Company. In other words, if T-Company can play the services of these three projects, it can greatly enhance the people's Satisfaction; 8 inequality quality elements, although the service in this part shows that it will not have a significant impact on the experience of the people, but the quality of service itself will not be excessively improved, so T-Company can reduce it. Part of the service's items, and rethink how to change in business strategy; as for However, there are 9 quality factors, which means that most people think that the service item should be owned by T-Company itself, and must have a certain level of professionalism and service quality in order to meet the needs of all types of people and avoid causing people not to Increase in satisfaction.

In addition, in the quality improvement indicators, T-Company has carried out further improvement and review of projects with higher scores to achieve twice the result with half the effort. The relevant analysis results are as follows:

\section{1) Increase customer satisfaction index}

According to Matzler \& Hinterhuber, the top five items for increasing the satisfaction index were calculated for the quality improvement indicators [7], as follows, "Taiwan maintains low and reasonable electricity prices", "the company provides multiple places for payment", "Taiwan electricity meter The fee and meter reading records are 
accurate and credible, "the company provides a rich and selective payment method", and "the electricity application can be supplied on time according to the user's demand schedule." The five listed items are all further Improvement and improvement of the project can not only meet the requirements of the people in terms of service quality, but also improve the public's satisfaction with T-Company itself.

\section{2) Reduce customer satisfaction indicators}

The first five items of the reduction of customer dissatisfaction indicators are "no delay in the issuance of electricity bills and receipts, and no delay in equipment dispatching," "equipment maintenance personnel have high efficiency in repairing and can restore power supply in the shortest time". "Taiwan maintains low and reasonable. The price of electricity, "the user's application for electricity to complete the power supply, the overall required operating time is short", "every work can be resumed according to the time of prior notice", these five items are all immediate needs of T-Company. The improvement of these projects can also effectively reduce the degree of dissatisfaction of the people with T-Company.

\section{SugGestions}

At the level of sustainable management, T-Company is a state-owned enterprise that monopolizes the market. Therefore, in addition to the mastery and acumen of the priority improvement projects, the operators must address the two key factors of hardware facilities and software services that customers will come into contact with. It is better to observe the customer's tendency and trend in each item's demand at any time, so as not only can improve the T-Company 's own positive service quality, but also improve the service quality and get rid of the past. It is equal to the customer's satisfaction and the traditional concept of "customers are arrogant about state-owned enterprises."

Furthermore, it is the service staff of the first line facing the customer, which refers to the software part. In many cases related to service quality, it often affects customers' perceptions. It is the first-line service personnel. It must not only have friendly and professional services, but also be indispensable for the enthusiasm of work. Therefore, it is very important for the service personnel to develop a professional service and training, and further to their professional development and re-education, which is a very important factor in cultivating a quality service personnel, including training service personnel to establish correct Service attitude and substantial professionalism are the key to retaining customers. Through continuous improvement of service concept, quality and attitude, on the one hand, customers will increase their trust. On the other hand, it is actually a good customer perception. Bad, and will directly affect the image of T-Company.

Finally, it is aimed at the signboard of T-Company Corporation to enhance its brand image. Although T-Company is a state-owned enterprise that monopolizes the market in Taiwan, how to establish a new concept so that customers will think of all the conditions described above when they hear about T-Company. That is, this brand of T-Company is guaranteed, not only for the company itself, but also for promoting the improvement of service quality. In addition, it is always a customer. Injecting new elements and innovative ideas, the author believes that T-Company should make good use of its own market advantages and abundant resources. Through different ingenuity and diversified service projects, customers will no longer have to limit power to T-Company. The monotonous stereotype, the combination of proactive service, inquiry, empathy and care are all important elements that can more grasp the customer. On the one hand, the service quality is improved, and it is almost perfect. On the other hand, using resources not only creates topics, but also improves customer satisfaction and willingness to accept.

\section{CONFLICT OF INTEREST}

There is no conflict of interest for this paper.

\section{AUTHOR CONTRIBUTIONS}

Chang-Hsien Hsu: The structure and ideas for entire paper.

Chiu-Yu Hung: Paper content and data analysis.

Yu- Hsuan Lan: Literature collection and charting.

Zheng-Ji Chen: Survey and collection.

\section{REFERENCES}

[1] Taiwan Power Company, Taiwan Power Company Sustainability Report, Taipei: Taipower Planning Office, 2018.

[2] A. Parasuraman, V. A. Zeithaml, and L. L. Berry, "A conceptual model of service quality and its implications for future research," Journal of Marketing, vol. 49, pp. 41-50, 1985.

[3] A. Parasuraman, V. A. Zeithaml, and L. L. Berry, "Servqual: A multiple-item scale for measuring consumer perceptions of service quality," Journal of Retailing, vol. 64, no. 1, pp. 12-40, 1988.

[4] A. Parasuraman, V. A. Zeithaml,and L. L. Berry, "Refinement and reassessment of the SERVQUAL scale," Journal of Retailing, vol. 67, pp. 420-450, 1991.

[5] F. Herzberg, The Motivation to Work, New York: John Wiley and Sons.1959.

[6] N. Kano, N. Seraku, F. Takahashi, and S. Tsuji, "Attractive quality and must-be quality, Hinshitsu Quality," The Journal of Japanese Society for Quality Control, vol. 14, no. 2, pp. 39-48, 1984.

[7] K. Matzler and H. H. Hinterhuber, "How to make product development projects more successful by integrating Kano's model of customer satisfaction into quality function deployment," Technovation, 1998, vol 18 , no. 1 , pp. $25-38$.

[8] CQM. "A Special issues on Kano's Methods for understanding customer-defined quality," Center for Quality Management Journal, vol. 2, pp. 3-35, 1993.

[9] Taiwan Power Company, Year 108 of Improving Service Quality Implementation Plan, Taipei: Taipower Planning Office, 2019.

[10] Ministry of Economic Affairs, Year 107 Annual Improvement of Service Effectiveness Implementation Plan, Taipei: State Business Committee of the Ministry of Economic Affairs, 2018.

[11] Y.F. Kuo, C. M. Wub, and W. J. Deng, "The relationships among service quality, perceived value, customer satisfaction, and post-purchase intention in mobile value-added services," Computers in Human Behavior, vol. 25, no. 4, pp. 887-896, 2009.

[12] Y.F. Kuo, C. M. Wub, and W. J. Deng, "IPA-Kano model:A new tool for categorising and diagnosing service quality attributes," Total Quality Management \& Business Excellence, vol. 23, no. 7-8, pp. 731-748, 2012.

[13] C. C. Yang, "Establishment and applications of the integrated model of service quality measurement," Managing Service Quality, vol. 13, no. 4, pp. 310-324, 2003.

Copyright (C) 2020 by the authors. This is an open access article distributed under the Creative Commons Attribution License which permits unrestricted 
use, distribution, and reproduction in any medium, provided the original work is properly cited ( $\underline{\text { CC BY } 4.0})$.

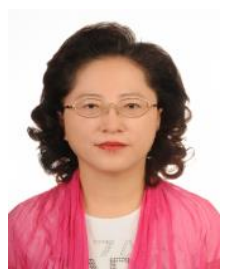

Hung-Chiu Yu was born on Jan. 14, 1964, Taiwan. She is now in the Department of Business Administration of PhD program in Asia University, Taichung City.

Hung is a successful business woman of trading business, she is the vice president of WellBall Industria Corp., their products are sell all over the world for over 20 years. Besides, she is participated in the woman's association for the underprivileged groups

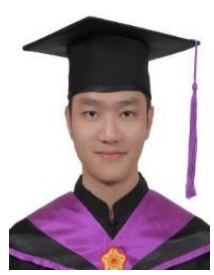

Yu-Hsuan Lan graduated from Graduate Institute of Ethnomusicology. He studies in the Department of Business Administration of $\mathrm{PhD}$ program in Asia University. He works at Cheng Shiu University. His Specializations are on ethnomusicology, Taiwan religious ritual and music, field work, music therapy, art management, percussion.

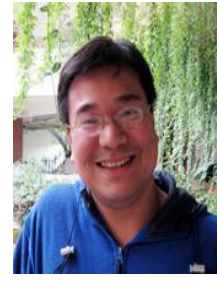

Chang-Hsien Hsu is a $\mathrm{PhD}$ in the Tamkang University Department of Management Sciences.

$\mathrm{He}$ is a former assistant in the National Chin-Y

University of Technology for excellence in teaching and learning.

$\mathrm{He}$ is also a lecturer at the National Chin-Y University, Tamkang University, and Chienkuo Technology University, and Chung Chou University.

$\mathrm{He}$ is an associate professor of the Department of Business Administration, Asia University, specializing in industry engineering and management, six standards improvement, service industry quality management.

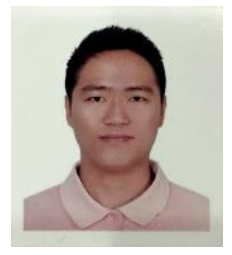

Zheng-Ji Chen is a technician of Taiwan Power Company. Zheng-Ji Chen specializes in maintenance, operation and fault repair of substation equipment and electric equipment, inspection of various equipment projects of substation and operation and maintenance of small island power plants. 